\title{
Obituary: Salleh Ben Joned (1941-2020)
}

\section{Malachi Edwin Vethamani}

University of Nottingham Malaysia

In 2020, Jalan SS19 1G, Subang Jaya became bereft of two Malaysian literary giants, KS Maniam on $19^{\text {th }}$ February and Salleh Ben Joned on $29^{\text {th }}$ October. Few knew that it was along this unknown suburban street that two of Malaysia's leading writers in English lived most of their adult lives and eventually died. Both were true to their reputations when I visited them. Maniam was home ready to receive me while I waited outside Salleh's house for an hour and then had to return the next day to meet him; he had forgotten about our appointment. It would have been my loss if I had not returned. That was to be the last time I got to meet my former lecturer and friend Salleh Ben Joned in 2017.

There is no denying that Salleh Ben Joned was a remarkable man. He will be remembered both as an unconventional and often controversial figure. He was multi-talented. A poet, critic, essayist, playwright, actor, columnist and an intellectual. He received a range of responses from adulation to abhorrence, to being labelled an apostate. While the Malaysian English language literary community embraced him, this was not the case with the Malaysian Malay literati. He was seen as a rebel and an outsider. The response that he received for the publication of his first collection of poems, Sajak-Sajak Saleh: Poems Sacred and Profane, is quite indicative of this antipathy towards him. Salleh highlights this in his Preface to Adam's Dream, pointing out that although in the first edition of Sajak-Sajak Saleh: Poems Sacred and Profane, "two-thirds of the content was in Malay' it was not reviewed in any Malay publication". This is also reflected in the much-repeated statement from national poet laureate Muhammad Haji Salleh on the publication of Sajak-Sajak Saleh: Poems Sacred and Profane that "the appearance of Salleh's book ... was the most traumatic experience for the Malay literary scene" and that "... to Salleh, nothing is sacred". 
Born in Melaka in 1941, even his birth date seems unclear as he says his birth certificate dates it as $5^{\text {th }}$ July though it is the $4^{\text {th }}$ that he celebrates. In his poem "born on the $4^{\text {th }}$ of July", he informs us "that soon after my head/ emerged from my mother's womb / the pendulum clock struck twelve". And so emerged Salleh Ben Joned onto Malaysian soil.

Salleh had his tertiary education in Australia as a Colombo Plan scholar in 1961. He was a student of Australian poet James McAuley, and their relationship developed into a life-long friendship. He returned to Malaysia in 1973 and taught in the English Department of Universiti Malaya until 1983. He then went on to be a freelance writer and househusband. He could be seen sending his children to school in Subang Jaya on weekday mornings.

He certainly made his presence felt in the local literary scene. In 1974, Salleh caused a stir when he publicly urinated at the opening of the "Towards a Mystical Reality" exhibition by artists Suleiman Esa and Reza Piyadasa, as his response to their artistic endeavour. Over the years, he was never far from controversy, if he wasn't in the centre of it.

He was often at odds with the Malay literati and this is quite apparent in what Muhammad Haji Salleh, in an interview with Anna Salleh, says of her father, Salleh Ben Joned:

He was naughty, and he was satirical of people and insulting too, of many. Of cultures, he was not very sensitive, no doubt. And Salleh also was profane. Malays are very sensitive of their race and about their religion. And Salleh wrote in a different style. From a different kind of soul. From (a) different culture, in fact. It was not Malaysian culture, and I don't think it was Australian either. It was Salleh's culture. So, when Salleh did write, the way that he did, used the words that he did, he created this trauma.

It certainly was not easy being Salleh Ben Joned. He was troubled by bouts of depression much of his adult life. Between these bouts he was lucid, happy and a brilliant writer. He seems to have carried a heavy burden as a writer. His daughter Anna mentions in a podcast for ABC radio that around 2000 he began Electroconvulsive therapy (ECT) and with that he began to slow down as a writer. The treatment took a heavy toll on his writing as it began to affect his memory and his capacity to write. Fortunately, despite this we still have a few publications post-2000: this includes the second edition of Sajak Sajak Saleh which was published as Poems Sacred and Profane 
(Pustaka Cipta, 2002), Nothing is Sacred (Maya Press, 2003), Adam's Dream (Silverfishbooks, 2007) and The Amok of Mat Solo (Silverfishbooks, 2011).

Salleh is remembered foremost as a poet, a bilingual poet. He claimed his muse spoke to him in his mother tongue, but as he had only a few Malay readers, he had to write in his second tongue, the English language. He published two volumes of poems. His second volume, Adam's Dream (2007), was a compilation of new English poems, with a few poems that had been published individually and some poems from his first compilation. They ranged from the very private and personal to the scathing and satirical poems that dwelled on the spiritual and the material world, mostly Malaysian.

In an audio cassette letter that Salleh sent to his daughter in 1975 (mentioned in a podcast on $\mathrm{ABC}$ radio), Salleh says, "the things I have been writing about is pain and happiness". There was much that pained Salleh about Malaysian society. His satirical wit birthed the word "Bumigeois" in his poems "Menage a Trois" and "Five-Star Poetry" to criticise the Malays/bumiputeras for their materialistic values.

As a poet he had a wide range both in style and content. He will be remembered for seething lines criticising hypocrisy, such as these from "Haram Scarum" :

Our one dislike we have to keep

to preserve our identity:

so long as we hate pigs and pray, we'll remain Moslem and Malay.

Or we can look at Salleh's take on the Malay dilemma in "Have Tempurung Will Travel”:

A bangsa entranced with modernisasi

Bumi by right, Malaysia merely in name;

We're both rooted in our old tradisi

And riveted to the New Malay Dream. 
This is a vast contrast to the personal and grieving father in the final stanza in Ria:

Joy means your name Ria

in the tongue of your blood

a tongue I must learn again

to sing the mystery of our pain

Among his well-known poems is one which was subjected to a few title changes and finally ended as "Malchin Testament". Salleh, while providing his critique of how Malaysians have made the English language their own, subtly invokes political satire:

we tekan words like our leders

tekan ebri they don't fancy,

por the real good of the nation.

it's a pity if dat you don't see.

As a playwright he will be remembered for his single published work, The Amok of Mat Solo. His poem "The Balada of Mat Solo or Mat Solo's Last Stand" written in 1981 germinated into this full-blown play. Mat Solo was Salleh's alter ego, and the play gave him the opportunity to have full rein to go amok with his character.

Salleh's more public presence was through his highly popular and provocative newspaper column, "As I Please", which ran in the New Straits Times from 1991 to 1994. It had a good following among the elite literary English language readers. It often sparked controversy and was much awaited by his fans. His newspaper column appeared when he pleased and drew to a close after three years. These articles were compiled and published in a volume called As I Please (Skoob Books, 1994) and a second publication appeared as Nothing is Sacred (Maya Press, 2003).

As a columnist he was provocative, to say the least, which is what his Editor Kee Thuan Chye wanted and certainly got. He always gave his honest take, be it on Malaysian politics and literature or world literature or Islam. In true Salleh fashion he offered his take on the concept of khalwat: 
Please note that khalwat is here used in the original sacred sense of the word, not the profane sense meant by our busybody religious bureaucrats. In Malaysian usage, the word has been corrupted to mean close sexual proximity .... I had my sacred khalwat on Pulau Besar in the hope of being granted barakah (grace) from God in the form of a literary revelation. (As I Please, 25 ${ }^{\text {th }}$ September 1991)

In his newspaper column, too, we read of his advocacy of cultural diversity; his notion of Malaysian culture was certainly not in line with the prescribed and engineered notion of national Malaysian culture:

On the question of cultural pluralism, we must be realistic. As realists have often pointed out, kebudayaan rojak is inevitable given the multi-ethnic nature of our society in which no one race truly dominates in terms of numbers. Anyway, what's wrong with kebudayaan rojak? Malaysians like rojak. It's good for them, and it helps nation building. Unity in diversity is certainly better for the vitality of our cultural life than the imposition of an artificially conceived national culture through legislation. A living culture, as everyone knows, grows naturally; it cannot be programmed or legislated according to an abstract recipe. (As I Please, $1^{\text {st }}$ July 1992)

Without slipping into nostalgia and sentimentality, I would like to close this tribute to Salleh with a little anecdote. In one of his As I Please columns in 1992, on Azanin Ahmad's dance drama "Keris", Salleh mentioned that he had been commissioned to write a poem for this production. On reading this, I sent him a postcard, saying: "Salleh, this smacks of literary whoredom". To this he replied: "I've now been called a literary whore, I take that as a compliment, Edwin."

Well, that commission certainly gave birth to one of Salleh's most read and discussed poems. It is probably his most iconic poem, "Spirit of the Keris". Of the poem, Salleh lightheartedly commented: "The keris is a powerfully phallic weapon, and inevitably my heated, 
perhaps over-fertile, imagination conceived the image of a giant phallus silently thrusting and awesomely bursting with the blessed seeds of a thousand islands." A few lines later we read the more serious poet Salleh's voice: "They say that if you put a kris (it has to be the right one, of course) close to your ear, you could hear the sound of its soul or semangat. The sound I heard when I was writing the poem was like a distant roar of the tiger, remote and ancient yet palpably close". These were the two-sides of a very complex Malaysian poet.

Salleh Ben Joned passed away on $29^{\text {th }}$ October 2020 but his presence in Malaysian literature in English is assured. His oeuvre, though small, will have a significant place in our growing literary tradition. 